(C) 2020 Katedra Białorutenistyki UW. Wydanie w otwartym dostępie na licencji CC BY-NC-ND (https://creativecommons.org/licenses/by-nc-nd/4.0/deed.pl)

ACTA ALBARUTHENICA 20: 2020

DOI: $10.32612 /$ uw.18988091.2020.20.pp.277-280

\title{
Дзмітрый Дзятко, Павел Міхайлаў, Мовазнаўцы. Нарысы па гісторы?беларускай лінгвістыкі, Выдавец А.М. Янушкевіч, Мінск 2017, 496 с.
}

$\mathrm{B}$ iałoruska książka pt. Językoznawcy. Szkice z historii lingwistyki białoruskiej w trzech rozdziałach przedstawia sylwetki 47 białoruskich językoznawców (w tym 11 kobiet). Monografia była rekomendowana do druku przez Katedrę Językoznawstwa Białoruskiego Państwowego Uniwersytetu Pedagogicznego im. Maksyma Tanka, a recenzowana przez językoznawcę dra Siarhieja Zaprudskiego i historyka dra Uładzimira Lachowskiego. Książkę wydał prywatny przedsiębiorca Andrej Januszkiewicz. Składa się ona $\mathrm{z}$ esejów opisujących zarówno fundamentalne prace uczonychfilologów, którzy na przestrzeni XIX-XXI ww. opracowywali różnorodne zagadnienia dotyczące lingwistyki wschodniosłowiańskiej, jak i ich życiorysy oraz fakty dotyczące działalności naukowej i dydaktycznej. Jak czytamy w przedmowie, książka była pisana na przestrzeni wielu dekad, gdyż eseje, z których się składa, powstawały w różnym czasie i w różnych warunkach, wiele z nich opublikowano wcześniej na łamach prasy zagranicznej. To, co je łączy w jedno wydanie książkowe, to zainteresowanie autorów oryginalna twórczą osobowością przedstawionych językoznawców. Autorzy nie kryją swego subiektywizmu w dobieraniu bohaterów książki, gdyż są zdania, że obiektywnie zrozumieć historię językoznawstwa białoruskiego można tylko dzięki uświadomieniu sobie, jaką rolę w niej ma naukowy subiektywizm (s. 3). Dlatego właśnie w książce prezentowane są oceny, alternatywne poglądy, a interpretacja przytoczonych faktów czasem różni się od ogólnie przyjętej. Autorzy uznali za ważne, by podkreślić to stanowisko w przedmowie, choć podtytuł książki już to niejako wyjaśnia. W języku polskim esej to krótka rozprawa naukowa lub literacka ujmująca temat w sposób subiektywny. Kto zna tę definicję, ten nie potrzebuje dodatkowych wyjaśnień.

Szczegółowość opisu sylwetki naukowej danego badacza uzależniona jest od znalezionych materiałów (w książce zdarzają się archiwalne zdjęcia i kopie dokumentów), od stopnia popularności danej osoby i celu, jaki stawiał sobie autor eseju. Autorzy mają świadomość, że nie ukazali wszystkich detali dotyczących życia i dorobku poszczególnych badaczy, stąd wyrażają nadzieję, że swoją pracę $\mathrm{w}$ tym zakresie wykonają także następne pokolenia, chcące poznać i uszanować korzenie lingwistyki białoruskiej.

W pierwszej kolejności opisano naukowe sylwetki znanych filologów, takich jak Iwan Nasowicz, Jauchim Karski, Alaksiej Szachmatau, Mikałaj Bajkou, Nina Wajtowicz, Ruben Awaniesau i in., którzy mieli ogromny wkład w kształtowanie się językoznawstwa białoruskiego. Autorzy podkreślają ich 
rolę w rozwoju nauki białoruskiej i podkreślają wagę czynników narodowych w ich życiu i działalności. Z drugiej strony opisują życie i pracę naukową językoznawców wcale, albo prawie wcale, nieznanych nawet wąskim specjalistom z historii językoznawstwa (np. Iwan Wołkau, Anton Karzon, Alaksandr Krutalewicz, Alena Kuryła, Iwan Macwiejenka, Michaił Suler, Sofia Rochkind i in.). Oczywiście w książce znajdziemy także bardziej znane nazwiska, takie jak Michaił Bułachau, Wiaczasłau Wiarenicz, Aleś Kaurus, Alaksandr Krywicki, Józefa Mackiewicz, Iosif Hajdukiewicz, Pawieł Sciacko, Fiodar Jankouski i in.

Dzięki lekturze książki czytelnik może poznać nie tylko ważne fakty naukowe czy dane bibliograficzne, lecz także ciekawe szczegóły biograficzne, np. że A. Szachmatau wiosną 1884 r. za swoją pracę magisterską pt. Badania $w$ dziedzinie fonetyki rosyjskiej po raz pierwszy w historii filologii rosyjskiej zamiast stopnia magistra uzyskał od razu stopień doktora (s. 135). Badacz był osobą lubiącą kontakty z ludźmi, szacuje się, że korespondował z 2 tys. korespondentów (m. in. z J. Karskim) i napisał od 17 tys. do 25 tys. listów (s. 136).

Oryginalnym pomysłem, który stanowi przejaw wspomnianego wcześniej subiektywizmu, było opisanie językowej spuścizny „czarodzieja poezji białoruskiej" (określenie Uładzimira Niaklajeua), czyli Ryhora Baradulina, zmarłego w marcu 2014 r. Jak dowodzą autorzy, R. Baradulin już od czasów szkolnych w swoich licznych notatnikach, których zachowało się ponad 200, notował nie tylko wiersze, lecz także wyrazy ludowe, przysłowia, zagadki etc. $\mathrm{z}$ jego rodzinnego rejonu uszackiego w obwodzie witebskim. Dzięki temu udało się zachować niezwykły dialektalny skarb tego obszaru Białorusi, który doczekał się także wydania drukiem pt. Вушацкі словазбор Рыгора Барадуліна (укл. Н. Давыдзенка, Мінск 2014). W eseju tym wspomniana publikacja jest dokładnie analizowana, a R. Baradulin ukazany jest jako badacz-dialektolog, etnolingwista i leksykolog-leksykograf uszackiej leksyki ludowej (dotyczącej nie tylko życia codziennego, lecz także onomastyki), który jako amator otwiera przed specjalistami wiele ciekawych perspektyw i faktów językowych, które mogą posłużyć do dalszych badań języka białoruskiego. Ten wymiar życia R. Baradulina powinni znać także literaturoznawcy.

Dla polskiego czytelnika ciekawym też będzie szkic o W. Wiareniczu, który oprócz etymologii i dialektologii, interesował się też historią polskiej białorutenistyki oraz polskimi dialektami na terenach byłego ZSRR, o czym świadczy 2-tomowe wydanie Польские говоры в СССР (1973). Mało kto wie, że W. Wiarenicz adaptował także na potrzeby szkolnictwa białoruskiego podręcznik autorstwa Aliny Michałowskiej do nauki języka polskiego dla III klasy (s. 322). W eseju szczegółowo opisano także wydane pośmiertnie Archiwum poleskie (Палескі архіў), do którego materiały zbierał W. Wiarenicz na Polesiu w ciągu 25 lat (1960-1985), a które przygotowane zostały do druku w 2009 r. m. in. przez polskie badaczki: Elżbietę Smułkową i Annę Engelking. 
W 2020 r. odszedł wybitny białoruski językoznawca i pedagog P. Sciacko, któremu także został poświęcony jeden $\mathrm{z}$ esejów. Warto się $\mathrm{w}$ tym czasie z nim szczegółowo zapoznać, bo nie każdy wie, że zdolny przyszły profesor bez egzaminów został przyjęty na Wydział Fizyczno-Matematyczny Grodzieńskiego Instytutu Pedagogicznego, z którego po 2 miesiącach przeniósł się na Wydział Literacki, po tym, jak zrozumiał, że prawdziwym jego powołaniem jest jednak filologia. Dla polskiego czytelnika szczególnie ważny może być fakt, że P. Sciacko był nie tylko dialektologiem, znawcą kultury języka białoruskiego, współautorem akademickiej gramatyki białoruskiej i podręczników dla studentów, lecz także brał udział w tworzeniu Słownika terminologii lingwistycznej białorusko-rosyjsko-polskiego i polsko-rosyjskobiałoruskiego (Białystok 1994). W 1988 r. odbył staż na Uniwersytecie Warszawskim, a przez 4 lata (1991-1994) prowadził zajęcia z gramatyki porównawczej języków wschodniosłowiańskich i języka polskiego w ówczesnej białostockiej filii Uniwersytetu Warszawskiego (obecnie Uniwersytet w Białymstoku).

Co ważne, autorzy opisują nie tylko znanych profesorów, lecz także zasłużonych dydaktyków. Do takich zaliczają m. in. dr Marię Kawaliową, docenta, zasłużonego nauczyciela BSSR, która w Instytucie Językoznawstwa Narodowej Akademii Nauk obroniła rozprawę doktorską dotyczącą czasówników zwrotnych w białoruskim języku literackim. Badaczka napisała ponad 80 prac naukowych i dydaktycznych, publikowała także podręczniki (także we współautorstwie ze wspomnianym wcześniej P. Sciacko). Miała szczególny charyzmat dopracowywania swych prac, stąd pierwsze wydanie podręcznika mogło się różnić w porównaniu z ostatnim nawet w 90 proc. (s. 349). M. Kawaliowa opracowywała także programy dydaktyczne, takie jak Wspótczesny literacki język białoruski czy Państwowy egzamin z języka białoruskiego. Prowadziła też autorskie konwersatoria, np. Stylistyka i kultura języka białoruskiego czy Składnia i interpunkcja. To docenienie pracowników dydaktycznych jest szczególnie ważne w obecnych czasach i chwała autorom za ten odważny subiektywny krok.

Każdy ze szkiców jest napisany bardzo ciekawie i profesjonalnie. Pokazuje szerszy kontekst powstawania prac naukowych i dydaktycznych. Tworzy swoistą opowieść o białoruskiej lingwistyce ostatnich wieków - o jej korzeniach, teraźniejszości i perspektywach rozwoju. Książka jest przeznaczona dla specjalistów w dziedzinie językoznawstwa, wykładowców, studentów i dla wszystkich interesujących się historią filologii białoruskiej. Wspaniale nadaje się na zajęcia $\mathrm{z}$ seminarium dyplomowego, podczas którego studenci i doktoranci mogą nie tylko poznać białoruskich lingwistów, lecz także zdobyć cenne informacje bibliograficzne, zobaczyć, jakie tematy i w jaki sposób były podejmowane, a jakie zagadnienia wciąż czekają na swoich badaczy. Pozwoli to znaleźć natchnienie do własnych prac i pomoże $w$ znalezieniu potrzebnych materiałów naukowych. W podobny sposób z wydania mogą skorzystać profesjonalni badacze-lingwiści oraz slawiści, gdyż książka w ciekawy sposób ukazuje dorobek i perspektywy rozwoju językoznawstwa 
280 | R a d o sław Ka leta

białoruskiego, stanowi jego swoistą wizytówkę i reklamę. Jest to nie wątpliwie pozycja obowiązkowa dla każdego badacza lingwistyki białoruskiej. Dlatego właśnie warto byłoby poszerzyć jej zasięg i przetłumaczyć na inne języki.

Radosław Kaleta rkaleta@uw.edu.pl 